\title{
Pendugaan Umur Simpan Produk Pastry dengan Quantitative Descriptive Analysis (QDA) dan Metode Arrhenius
}

\author{
Determination of Shelf-life Pastry Product by \\ Quantitative Descriptive Analysis (QDA) and Arrhenius Method
}

\author{
Dase Hunaefi $\left.{ }^{1,2}\right)^{*}$ dan Fitriyah Ulfah ${ }^{1)}$ \\ ${ }^{1)}$ Departemen Ilmu dan Teknologi Pangan, Fakultas Teknologi Pertanian, Institut Pertanian Bogor, Bogor \\ 2) Southeast Asian Food and Agricultural Science and Technology Center, LPPM, Institut Pertanian Bogor, Bogor
}

\begin{abstract}
The Unclear and limited shelf-life of pastry become the problem for SMEs. The objective of the study was to determine shelf-life using sensory evaluations by Quantitative Descriptive Analysis (QDA). The fresh pastries are Croissants with chocolate and cheese fillings and also in Apple Danishes. As a supporting data, proximate analysis was done on the three samples. The rancidity analysis was done using the Thiobarbituric Acid (TBA) method to measure the malondialdehyde level. TBA method was conducted. Determination of shelf-life Sensory evaluations was performed by ten trained panelists analysed sensory characteristic changes during storage. The sensory characteristics identified were taste, aroma, rancidity, hardness, crust and crumb, and the filling consistency changes during storage. Shelf-life apple danish, chocolate croissant and cheese croissant by QDA in a row were 6, 6 and 5 days. Meanwhile, Arrhenius method showed that fresh pastries have much longer shelf-life. Shelf-life Apple danish, chocolate croissant and cheese croisaant by Arrhenius method were 48, 35 and 48 days, respectively. Therefore, in the case of shelf-life prediction of pastries, QDA method resulted better accurate method in prediction of shelf-life.
\end{abstract}

Keywords: croissant, danish, QDA, rancidity, shelf-life

\begin{abstract}
Abstrak. Umur simpan dari pastry yang terbatas dan tidak diketahui secara jelas menjadi masalah bagi Usaha Mikro Kecil dan Menengah (UMKM). Tujuan dari penelitian ini adalah untuk menentukan umur simpan produk pastry secara organoleptik dengan Quantitative Descriptive Analysis (QDA). Pengujian dilakukan pada produk pastry, yaitu Croissant dengan isi cokelat dan keju serta Apple Danish. Sebagai data pendukung, dilakukan analisis proksimat terhadap ketiga sampel. Analisis ketengikan dilakukan menggunakan metode Thiobarbituric Acid (TBA) untuk mengukur kadar malonaldehid. Uji Organoleptik dilakukan oleh sepuluh panelis yang telah melewati tahap seleksi hingga dilatih sehingga dapat mengidentifikasi perubahan karakteristik sensori selama penyimpanan. Karakteristik yang diidentifikasi, antara lain rasa, aroma, ketengikan, kekerasan, crust dan crumb serta konsistensi dari isiannya yang timbul selama penyimpanan. Umur simpan dengan QDA untuk produk apel danish, croissant cokelat serta croissant keju secara berturut-turut adalah adalah 6, 6 dan 5 hari. Sedangkan dengan menggunakan metode Arrhenius, umur simpan produk pastry segar jauh lebih lama yaitu 48, 35 dan 48 hari untuk apple danish, chocolate croissant dan cheese croisant. Dengan demikian, untuk pendugaan umur simpan produk pastry, metode QDA menghasilkan umur simpan jauh lebih akurat dibandingakan dengan metode Arrhenius.
\end{abstract}

Kata Kunci: croissant, danish, ketengikan, QDA, umur simpan

Aplikasi Praktis: Hasil penelitian ini memberikan informasi kepada pelaku usaha, khususnya UMKM
BearKery tentang umur simpan dari produk pastry yang diproduksi. Umur simpan ini akan
mempermudah UMKM untuk memasarkan lebih luar produk pangannya dan menentukan jenis kemasan
apa yang lebih tepat untuk digunakan sehingga dapat meningkatkan umur simpannya produk pastry
seperti halnya yang diproduksi oleh perusahaan.

\section{PENDAHULUAN}

Produksi produk bakery di Indonesia pada tahun 2009 yaitu 27908 ton dan terus mengalami peningkatan hingga pada tahun 2013 mencapai 35586 ton. Jumlah produksi bakery berbanding lurus dengan konsumsi ratarata produk bakery di Indonesia yang terus meningkat dari tahun 2009 yaitu $0.121 \mathrm{~kg} / \mathrm{kapita} /$ tahun hingga tahun 2013 sebesar mencapai $0.144 \mathrm{~kg} / \mathrm{kapita} / \mathrm{tahun}$ (BPS 2015). Menurut Global Industry Analysis (2017), tingkat konsumsi rata-rata pada bulan Juli 2017 untuk produk bakery di Indonesia mencapai $4 \mathrm{~kg} /$ kapita. Angka tersebut masih relatif rendah dibandingkan konsumsi produk bakery di negara-negara lainnya. Produk bakery terbagi menjadi produk yang sangat beragam, salah satunya pastry. Perbedaan produk pastry dengan produk lainnya yaitu flaky dan mudah patah dibagian dalamnya karena adanya pelapisan oleh korsvet. Karakteristik yang paling utama dalam penentuan mutu pastry diantaranya tekstur dan oksidasi lipid yang ditandai dengan munculnya off-flavor. Kandungan lemak yang tinggi akibat pelapisan adonan dengan korsvet menyebabkan pastry mudah mengalami ketengikan selama penyimpanan.

Korespondensi: dashcbdk@apps.ipb.ac.id 
Kedua karakteristik tersebut dapat memengaruhi umur simpan pada pastry.

Menurut PP RI No. 69 Tahun 1999 tentang Label dan Iklan Pangan, pencantuman tanggal kadaluwarsa pada produk dengan daya tahan lebih dari tiga bulan diperbolehkan hanya mencantumkan bulan dan tahun kadaluwarsa. Sedangkan untuk pangan dengan daya tahan hanya 24 jam seperti roti tidak perlu mencantumkan label pangan. Akan tetapi, menjadi nilai tambah bagi produk apabila dapat mencantumkannya karena konsumen menjadi lebih merasa aman dalam mengonsumsinya. Pendugaan umur simpan produk pangan dapat dilakukan dengan mengevaluasi perubahan mutunya selama penyimpanan. Pada beberapa macam produk pangan, penurunan penerimaan secara sensori dapat mendahului umur simpan yang telah ditetapkan secara kimia dan mikrobiologi (Oliveira et al. 2012). Studi ini menggunakan Real Time testing untuk melihat umur simpan dari produk dengan menggunakan pendekatan sensori yang juga biasa disebut Sensory Shelf-Life Testing (SSLT) (Patra 2016). Analisis sensori yang sesuai untuk pengujian umur simpan adalah uji deskriptif (Heymann dan Lawless 2010). Salah satu metode yang dapat digunakan, yaitu Quantitative Descriptive Analysis (QDA). QDA merupakan salah satu uji sensori secara deskriptif untuk mengidentifikasi karakteristik sensori yang menjadi ciri khas dalam suatu produk pangan dan digambarkan pula secara kuantitatif berupa intensitas dari karakteristik tersebut. Metode uji deskriptif melibatkan atribut sensori secara objektif, deskripsi dan kuantitatif terhadap produk yang di analisis oleh panelis terlatih (Maharani dan Fibrianto 2015). Maka dari itu tujuan penelitian ini adalah untuk menentukan umur simpan produk pastry dengan menggunakan pendekatan QDA dan dibandingkan dengan metodeArrhenius.

\section{BAHAN DAN METODE}

\section{Bahan dan Alat}

Bahan utama yang digunakan adalah 3 macam pastry yaitu croissant keju, croissant cokelat dan appel danish yang diperoleh dari UMKM BearKery. Ketiga jenis pastry disimpan pada suhu 25,35 , dan $45^{\circ} \mathrm{C}$ pada penyimpanan hari ke- $0,3,6,9,12,15$ masing-masing sampel dilakukan pengukuran kadar MDA. Sampel untuk analisis organoleptik disimpan pada suhu ruang dan dilakukan analisis setiap hari selama satu minggu. Bahan kimia yang digunakan yaitu pereaksi TBA $(0.2883 \mathrm{~g}$ TBA/100 $\mathrm{mL}$ asam asetat glasial $90 \%$ ), $\mathrm{HCl}$, akuades, heksana, $\mathrm{H} 2 \mathrm{SO} 4, \mathrm{~K} 2 \mathrm{SO} 4, \mathrm{HgO}, \mathrm{NaOH} 30 \%$, Indikator $\mathrm{PP}$, asam borat, bromocresol green $0.1 \%$, merah metil $0.1 \%$ dalam alkohol $95 \%, \mathrm{HCl} 0.01 \mathrm{~N}$, sukrosa, $\mathrm{NaCl}$, MSG, asam sitrat, kafein dan air mineral. Sedangkan alat alat yang digunakan adalah Texture Analyzer, spektrofotometer, pipet mohr, pipet tetes, neraca analitik, alumunium foil, inkubator, labu destilasi, wadah plastik, label, tabung reaksi bertutup, labu takar, gelas piala, gelas pengaduk, mortar, spatula, cawan aluminium, oven, desikator, gegep, tanur, cawan porselen, soxhlet, kertas saring, kapas, labu kjeldahl, penangas, erlenmeyer, buret, batu didih, gelas kaca, sendok plastik

\section{Analisis proksimat}

Analisis prokimat dilakukan sebagai data pendukung pada penelitian ini. Analisis yang dilakukan yaitu kadar air, abu, protein, lemak dan karbohidrat by difference. Analisis dilakukan dengan tiga kali ulangan secara duplo berdasarkan pedoman Association of Official Analytical Chemistry (AOAC 2012).

\section{Seleksi panelis}

\section{Perekrutan dan pengisian kuesioner}

Perekrutan dilakukan terhadap mahasiswa Institut Pertanian Bogor Departemen Ilmu dan Teknologi Pangan. Mahasiswa yang tertarik terhadap uji sensori, tidak alergi terhadap gluten, menetap di Bogor untuk beberapa bulan ke depan. Calon panelis diminta mengisi kuesioner mengenai latar belakang dari panelis serta bagaimana konsumsi dan pengetahuannya terhadap pastry. Selain itu juga berisi kebersediaan panelis mengikuti tahapan uji dari awal hingga akhir penelitian dan memiliki kesehatan yang baik.

\section{Uji seleksi panelis}

Uji seleksi panelis terdiri dari uji pengenalan aroma dan rasa dasar, uji segitiga serta uji ranking. Uji aroma dasar dilakukan untuk mengetahui apakah organ penciuman panelis dapat berfungsi dengan baik. Pengujian menggunakan smelling strip yang kemudian disimpan pada plastik klip. Panelis yang terpilih adalah panelis yang dapat menjawab dengan benar $50 \%$ dari total sampel yang disediakan. Uji rasa dasar dilakukan untuk mengetahui apakah panelis dapat membedakan kelima rasa dasar yaitu rasa manis, asin, asam, pahit dan umami. Panelis yang terpilih adalah panelis yang dapat menjawab dengan benar $80 \%$ dari total sampel yang disediakan (Utami et al. 2006). Uji segitiga dilakukan untuk mengetahui apakah panelis dapat mendeteksi perbedaan atribut antara sampel dengan intensitas yang berbeda. Sampel berupa larutan rasa manis dan asin dengan masing-masing 6 konsentrasi berbeda. Panelis yang terpilih adalah panelis yang dapat menjawab dengan benar $50 \%$ dari total sampel yang disediakan. Uji rangking dilakukan untuk mengetahui apakah panelis dapat mengurutkan sampel dengan beberapa konsentrasi yang berbeda. Sampel berupa rasa manis dan rasa asin dibuat dengan empat konsentrasi berbeda. Panelis yang terpilih adalah panelis yang dapat mengurutkan secara tepat larutan dari konsentrasi rendah ke konsentrasi tertinggi (Meilgaard et al. 2007).

\section{Pelatihan panelis}

Setelah mendapatkan panelis yang telah melalui tahap seleksi sebelumnya, panelis kemudian akan dilatih untuk mengenal karakteristik dari sampel uji. Panelis dikenalkan pada sampel yang baru diproduksi untuk dikenali karakteristiknya sebagai produk yang masih 
baik. Selain itu, panelis juga dikenalkan produk yang telah mengalami kerusakan tekstur dan aroma tengik. Sampel dengan tekstur yang rusak disimpan pada penyimpanan dengan $\mathrm{RH}$ garam jenuh $\mathrm{NaCl}$ selama dua minggu (Budijanto et al. 2010). Sampel yang dirusak untuk mengeluarkan aroma tengik disimpan pada inkubator suhu $60^{\circ} \mathrm{C}$ selama dua minggu. Panelis dikenalkan pada skala garis dengan nilai 0 sampai dengan 10 .

Identifikasi karakteristik sensori produk dengan Focus Group Discussion (FGD) dilakukan diawal sebelum dilakukan pelatihan panelis sehingga didapatkan kesepakatan dari para panelis apa saja karakteristik sampel yang akan mengalami perubahan selama penyimpanan sampel. Jurnal yang dijadikan acuan dalam melakukan FGD yaitu menurut Hozova et al. (2002) tentang Sensory Quality of Stored Croissant-type Bakery Product. Nilai standar dibutuhkan untuk dijadikan acuan oleh panelis untuk penilaian sampel dengan QDA. Standar yang digunakan sebagai acuan yaitu sampel yang baru diproduksi.

\section{Pengujian umur simpan dengan QDA}

Metode QDA dapat digunakan untuk mendeskripsikan produk, pengujian dalam melakukan perubahan formulasi, pengaruh lama penyimpanan dan pengemasan (Rahmawati et al. 2015). QDA menilai intensitas dari masing-masing atribut sensori dan akan dibandingkan dengan nilai standar yang telah ditentukan dari tahap pelatihan sebelumnya. Dengan skala garis, panelis akan memberikan nilai intensitas sesuai interval data dan akan membandingkannya dengan standar yang telah ditentukan. Garis horizontal yang telah diberikan, kemudian dikonversi secara digital untuk menandai nomer berdasarkan progam yang telah ditetapkan sebelumnya dan masukkan data untuk dianalisis (Meilgaard et al. 2007).

\section{Pengujian kadar malonaldehid (MDA) menggunakan TBA}

Kkerusakan lipid dapat berupa ketengikan, perubahan rasa maupun aroma. Pemecahan ikatan karbon selama peroksidasi lipid menyebabkan pembentukan alkanal seperti MDA. Satu molekul MDA akan berikatan dengan dua molekul TBA dan membentuk kompleks MDA-TBA yang menghasilkan warna merah (ketaren 2005). Sampel yang disimpan dikemas dengan plastik OPP. Sampel ditimbang 10 gram, kemudian ditambahkan $97.5 \mathrm{~mL}$ akuades. Tambahkan $2.5 \mathrm{~mL} \mathrm{HCl} 4 \mathrm{~N}$ dan destilasi dengan pemanasan setinggi mungkin hingga diperoleh destilat sebanyak $50 \mathrm{~mL}$. Destilat yang diperoleh diaduk dan dipindahkan $5 \mathrm{~mL}$ kedalam tabung reaksi bertutup dan ditambahkan $5 \mathrm{~mL}$ reagen TBAasetat. Panaskan tabung pada air mendidih selama 35 menit. Larutan blanko dibuat dengan menggunakan $5 \mathrm{~mL}$ akuades dan $5 \mathrm{~mL}$ pereaksi, lakukan seperti perlakuan pada sampel. Setelah dididihkan, lalu dinginkan dengan air pendingin selama 10 menit. Ukur absorbansinya dengan spektrofotometer pada panjang gelombang 528 $\mathrm{nm}$ dengan larutan blanko sebagai titik nol. Setelah mendapatkan nilai absorbansi, maka hitung nilainya menggunakan rumus: (Tarladgis et al. 1960). Analisis ini dilakukan dengan tiga kali ulangan secara duplo.

$$
\mathrm{TBA}=7.8 \mathrm{~A}
$$

dimana, TBA = Jumlah malonaldehid $(\mathrm{g})$ per kilogram sampel; A = Absorbansi sampel.

\section{HASIL DAN PEMBAHASAN}

\section{Analisis proksimat}

Kadar air untuk croissant lebih rendah dibandingkan kadar air danish (Tabel 1), hal ini disebabkan oleh danish yang diisi dengan selai apel mengandung kadar air yang cukup tinggi. Croissant dengan isian coklat batang memiliki kadar air paling rendah. Kadar air dari coklat batangan menurut SNI 3749-2009 dalam Negara et al. (2014), yaitu maksimum 2\%. Menurut Desrosier (2008), kadar air produk pangan dipengaruhi oleh proses pemasakan. Akan tetapi karena selai memiliki kandungan gula yang sangat tinggi, air dalam selai diserap oleh gula sehingga sedikit air bebas yang tersedia. Saat ini hanya ada standar kadar air roti manis menurut SNI 01-38401995 maksimal 40\%.

Tabel 1. Analisis proksimat

\begin{tabular}{llll}
\hline Karakteristik & $\begin{array}{c}\text { Croissant } \\
\text { Cokelat }\end{array}$ & $\begin{array}{c}\text { Croissant } \\
\text { Keju }\end{array}$ & Apple Danish \\
\hline Air $(\% \mathrm{bb})$ & $17.07 \pm 0.26^{\mathrm{a}}$ & $24.57 \pm 0.11^{\mathrm{b}}$ & $31.31 \pm 0.64^{\mathrm{c}}$ \\
Abu $(\% \mathrm{bk})$ & $1.22 \pm 0.08^{\mathrm{a}}$ & $1.77 \pm 0.00^{\mathrm{b}}$ & $1.07 \pm 0.01^{\mathrm{c}}$ \\
Protein $(\% \mathrm{bk})$ & $7.25 \pm 0.11^{\mathrm{a}}$ & $7.78 \pm 0.18^{\mathrm{a}}$ & $5.99 \pm 0.13^{\mathrm{b}}$ \\
Lemak (\%bb) & $36.83 \pm 0.43^{\mathrm{a}}$ & $36.22 \pm 0.83^{\mathrm{a}}$ & $30.68 \pm 0.14^{\mathrm{b}}$ \\
$\begin{array}{l}\text { Karbohidrat by } \\
\text { difference }(\% \mathrm{bk})\end{array}$ & $37.62 \pm 0.72^{\mathrm{a}}$ & $29.66 \pm 0.76^{\mathrm{b}}$ & $30.95 \pm 0.65^{\mathrm{b}}$ \\
\hline
\end{tabular}

Keterangan: Angka-angka yang diikuti huruf yang sama menunjukkan hasil yang tidak berbeda nyata pada taraf signifikansi 0.05

Hasil analisis kadar abu menunjukkan perbedaan signifikan antara croissant cokelat, croissant keju dan apple danish. Menurut Saloko et al. (2016), kadar abu pada patiseri sangat dipengaruhi oleh jenis tepung yang digunakan. Kadar abu produk patiseri dengan substitusi mocaf sebesar $1.64 \%$, sedangkan untuk kadar abu dari tepung terigu maksimum yaitu 2\% (BSN 2006). Kadar abu apple danish paling rendah karena selai yang digunakan merupakan bahan-bahan organik dan tidak banyak mengandung mineral. Kadar abu pada keju paling tinggi hal ini dikarenakan kandungan mineral pada keju olahan cukup tinggi karena keju jenis ini mengandung tambahan garam pengemulsi (Pratomodjati 2007). Hasil analisis kadar protein croissant cokelat dan croissant keju tidak berbeda nyata sedangkan pada apple danish kadar proteinnya hanya sebesar $5.99 \%$. Keju memiliki kandungan protein yang tinggi karena merupakan produk hasil penggumpalan dari protein susu. Kadar protein sangat dipengaruhi oleh komposisi tepung terigu yang digunakan serta penambahan isinya. Hasil analisis kadar lemak pada croissant cokelat dan keju tidak berbeda signifikan sedangkan untuk danish berbeda signifikan. Kadar lemak pada croissant lebih besar dibandingkan kadar lemak pada danish, hal ini dipengaruhi oleh isian dari masing- 
masing produk. Kandungan lemak pada keju berkisar antara $35-40 \%$ sedangkan kandungan lemak pada cokelat batangan yaitu 43\% (Negara et al. 2014).

Penentuan kadar karbohidrat dalam analisis proksimat ini dilakukan secara by difference yaitu jumlah kadar air, abu, protein, lemak dan karbohidrat dalam produk adalah $100 \%$. Hasil analisis kadar karbohidrat croissant keju dan apple danish tidak berbeda nyata signifikan sedangkan croissant cokelat berbeda nyata. Kandungan karbohidrat yang tinggi pada croissant cokelat selain dari tepung, ditambah juga dengan karbohidrat dari cokelat batangan yang digunakan sebagai isian yaitu sebesar 48\% (Negara et al. 2014).

\section{Pendugaan umur simpan dengan QDA}

\section{Seleksi panelis}

Pengisian kuisioner dilakukan oleh 53 mahasiswa ITP IPB. Berdasarkan kuisioner, sekitar $98.10 \%$ mahasiswa yang mengisi kuisioner pernah mengonsumsi produk pastry. Mereka menggambarkan karakteristik produk pastry yang mereka ketahui diantaranya teksturnya yang renyah, rasanya asin dan manis serta berminyak. Dari 53 responden, hanya 43 yang datang untuk mengikuti tahap seleksi pertama yaitu uji rasa dasar dan aroma dasar. Seleksi pertama yaitu uji rasa dasar dan aroma dasar dijadikan penyaring pertama untuk banyaknya panelis yang mengikuti tahapan ini. Tahap pertama uji tersebut hanya menyisakan 12 panelis yang memenuhi kriteria kelulusan uji. Sebanyak 12 panelis yang lolos ketahap selanjutnya mampu mendeskripsikan dengan baik aroma yang tercium, bahkan hingga menyebutkan jenis produk tertentu yang dianggap sama dengan sampel. Keadaan tersebut menunjukkan bahwa panelis yang lolos memiliki ingatan yang baik terhadap aroma yang sudah pernah dikenali dengan aroma yang diujikan (Rahmadhani dan Fibrianto 2016). Tahapan seleksi selanjutnya yaitu uji segitiga dan uji rangking. Dari 12 panelis yang lolos ditahap pertama, hanya 10 panelis yang lolos tahapan uji kedua ini. Dua orang panelis tidak memenuhi kriteria kelulusan pada uji segitiga karena kesulitan membedakan intensitas rasa manis dan asin. Jumlah minimum panelis terlatih pada suatu uji deskriptif sebanyak 6 panelis (BSN 2006), semakin banyak panelis maka semakin baik data yang di repesentatifkan karena variasi antar individu dapat diseimbangkan (Arkanti 2007).

\section{Pelatihan panelis}

Pengenalan produk dilakukan diawal pelatihan dan dilakukan FGD untuk menyamakan konsep atribut sensori produk tersebut. Dari FGD didapatkan tujuh atribut yang akan dinilai pada sampel yaitu aroma keseluruhan, ketengikan, rasa keseluruhan, crust, crumb, hardness, dan filling consistency (Gambar 1). Pelatihan pengenalan sampel yang baik dan sampel rusak dilakukan sebanyak 2 kali pada minggu yang berbeda untuk melihat kemampuan panelis dalam mengingat atribut rasa sensori pada produk. sampel yang mengandung lemak cukup tinggi akan mudah mengalami oksidasi lemak yang memunculkan ketengikan pada pangan. Kerusakan tersebut dapat disebabkan oleh beberapa faktor, dan salah satunya yaitu suhu, semakin tinggi suhu penyimpanan maka kerusakan akan lebih mudah terjadi (Sartika 2009).

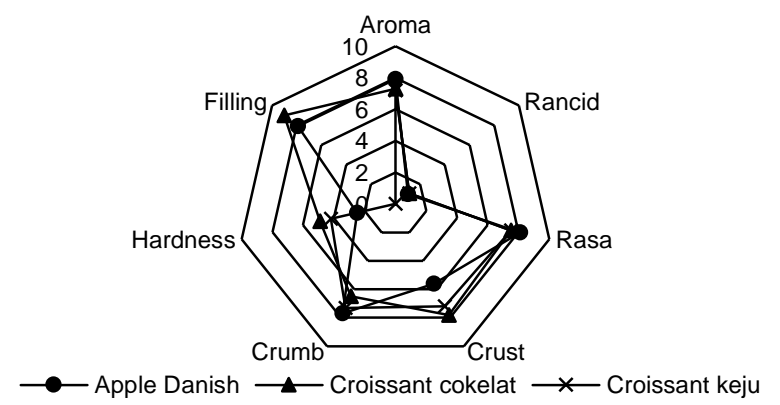

Gambar 1. Konsensus karakteristik sensori standar

Setelah mengenal karakteristik sampel yang akan diuji, panelis diminta untuk melakukan konsensus terhadap karakteristik-karakteristik sensori yang telah ditentukan. Hasil konsensus menunjukkan bahwa Standar untuk ketiga sampel memiliki penerimaan aroma dan rasa yang hampir sama. Untuk karakteristik tekstur, apple danish bersifat lebih lembut dilihat dari nilai crust dan hardness yang cukup rendah, hal tersebut dikarekan kadar air dari apple danish. Aroma tengik pada ketiga standar sudah mulai terdeteksi meskipun sangat samar dengan nilai 1 . Adanya aroma tengik yang terdeteksi tersebut dapat disebabkan oleh kerusakan akibat proses pemanggangan awal produk kerena pemanggangan dilakukan pada suhu $200^{\circ} \mathrm{C}$ dan lemak mengalami kerusakan pada pemanasan suhu tersebut (Ketaren 2005).

\section{Uji quantitative descriptive analysis}

Quantitative descriptive analysis (QDA) menilai intensitas dari masing-masing atribut sensori dan akan dibandingkan dengan nilai standar yang telah ditentukan dari tahap pelatihan sebelumnya. Ketiga jenis sampel akan diuji selama 7 hari penyimpanan dan akan dinilai setiap harinya. Pastry yang telah disimpan disajikan bersamaan dengan standar agar memudahkan panelis dalam memberikan penilaian terhadap intensitas masingmasing atribut. Pengujian sampel dengan QDA untuk menghitung umur simpan ini dititik beratkan pada aroma rancid, yaitu dengan batas maksimal nilai 4 berdasarkan hasil diskusi para panelis. Panelis menganggap pada nilai tersebut aroma rancid sudah cukup kuat dan dianggap sudah tidak dapat diterima lagi. Diketahui bahwa apple danish memiliki tingkat kekerasan yang tidak teratur selama penyimpanan. Selain itu apple danish memiliki karakteristik yang paling lembut karena kadar airnya yang sangat tinggi. Jika dibandingkan dengan standar sampai hari keenam, apple danish masih dapat diterima panelis karena nilainya tidak mengalami perubahan sampai setengah nilai awalnya. Pada hari ketujuh, atribut rancid sudah mencapai 4.11 dan apple danish sudah mulai ditumbuhi oleh kapang sehingga sudah tidak dapat dikonsumsi lagi (Gambar 2). Karakteristik aroma, rasa, dan filling consistensy pada croissant cokelat tidak mengalami perubahan sampai setengah dari mutu standar 
hingga hari keenam. Untuk atribut tekstur mengalami perubahan yang signifikan terutama pada crumb. Kadar air yang lebih rendah dibandingkan apple danish membuat croissant lebih kering dan lebih mudah menjadi keras. Meskipun terus bertambah keras dan kering akan tetapi aroma dan rasanya masih dapat diterima oleh panelis hingga penyimanan hari keenam. Pada hari ketujuh croissant cokelat juga sudah tidak dapat diterima karena nilai atribut rancid telah mencapai nilai 4.22 (Gambar 3).

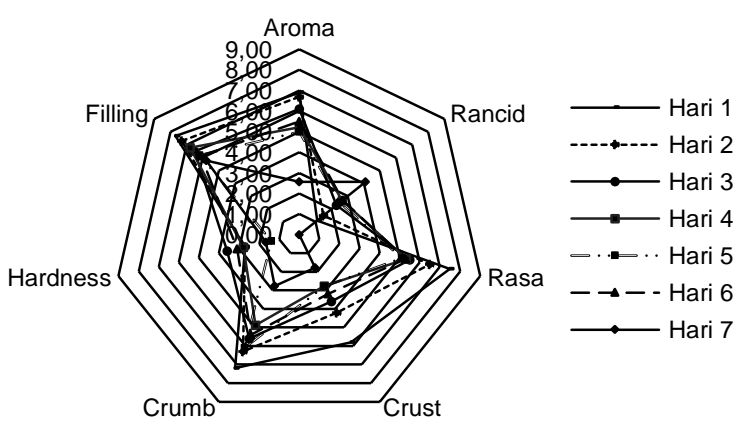

Gambar 2. Hasil QDA Apple Danish

Sebagian besar atribut sensori pada croissant keju mengalami perubahan yang signifikan, tetapi untuk hardness tidak mengalami banyak perubahan sampai penyimpanan hari kelima, produk masih dapat diterima oleh panelis sedangkan saat penyimpanan hari keenam mengalami perubahan nilai yang cukup besar untuk atribut aroma, rancid, rasa, crust dan crumb. Hal ini menunjukkan bahwa panelis mulai merasakan perubahan mutu yang cukup besar pada produk tersebut. Atribut rancid pada hari keenam telah mencapai nilai 4.10 sehingga produk sudah tidak dapat diterima (Gambar 4).
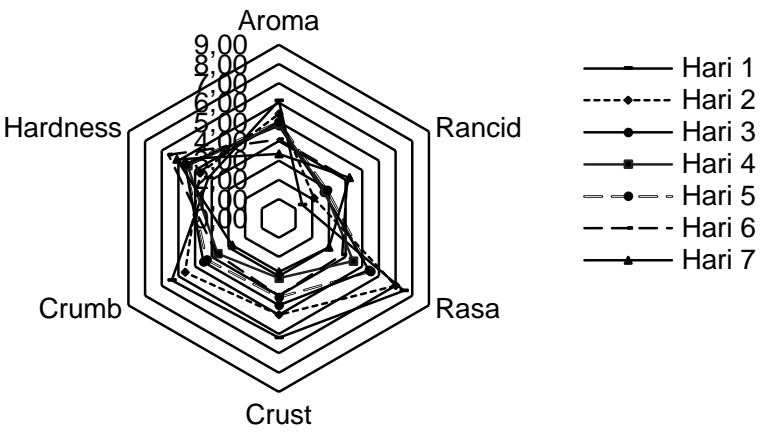

Gambar 3. Hasil QDA croissant cokelat
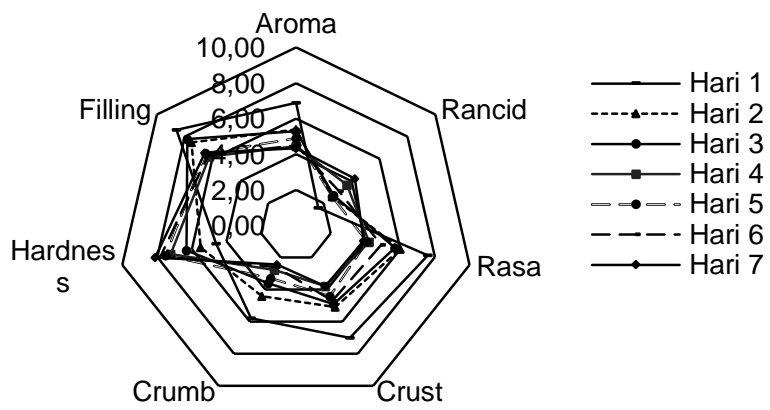

Gambar 4. Hasil QDA croissant keju

Perhitungan umur simpan dengan metode arrhenius

Perhitungan kadar MDA akan menghasilkan persamaan Arrhenius. Produk apple danish menunjukkan perubahan yang paling tidak stabil. Hal ini diakibatkan oleh adanya pertumbuhan kapang pada produk dihari ke6 , sedangkan pada produk croissant kapang baru tumbuh pada penyimpanan hari ke-9. Menurut Mizana et al. (2016), kapang yang banyak tumbuh pada produk bakery adalah kapang jenis Aspergillus sp yang merupakan Salah satu kapang penghasil lipase (Sharma et al. 2001). Selain adanya pertumbuhan kapang, faktor kesalahan lainnya yaitu adanya substansi lain dalam produk. Selain aldehid dan MDA substansi lain dapat juga berikatan oleh TBA antara lain keton, ketosteroid, asam, ester, gula, urea, asam amino, protein teroksidasi, piridin dan pirimidin (Sans dan Chozas 1998). Substansi-substansi tersebut dapat mengganggu pembacaan nilai TBA sehingga hasil analisis pada produk pastry sangat fluktuatif.

Menurut Mirazhi dalam Steele (2009), model kinetika Arrhenius akan dinyatakan valid apabila kondisi kadar air dan Aw tetap pada suhu yang berbeda. Croissant dan Danish memiliki nilai Aw yang cenderung meningkat selama penyimpanan meskipun peningatan tersebut tidak signifikan (Ismail 2018). Persamaan yang dihasilkan dari grafik sesuai Gambar 5 dan Gambar 6 merupakan model yang menggunakan satu jenis parameter dan memiliki tingkat kecepatan reaksi yang paling tinggi. Hal tersebut dapat menyebabkan deviasi nilai yang sangat besar saat perhitungan dengan persamaan umur simpan (Mirazhi dalam Steele 2009). Hasil nilai TBA (Tabel 2) pada croissant cokelat, croissant keju dan apple danish menunjukkan nilai R2 yang lebih tinggi pada persamaan orde 1 (Tabel 3). Menurut Labuza dalam Arpah (2007), kerusakan yang terjadi pada produk akibat reaksi oksidasi lipid dan pencoklatan non-enzimatis termasuk kedalam reaksi orde 0. Setelah ditentukan orde reaksi yang akan digunakan, persamaan terebut digunakan untuk menghitung nilai $\mathrm{k}$ dan juga umur simpan.

Tabel 2. Persamaan Arrhenius dan regresi setiap produk

\begin{tabular}{lcccc}
\hline Produk & Persamaan Orde 0 & $\begin{array}{c}\text { Regresi } \\
\text { Orde 0 }\end{array}$ & Persamaan Orde 1 & $\begin{array}{c}\text { Regresi } \\
\text { Orde 1 }\end{array}$ \\
\hline $\begin{array}{l}\text { Croissant } \\
\text { Cokelat }\end{array}$ & $\mathrm{y}=248.34 \mathrm{x}-4.4629$ & 0.0156 & $\mathrm{y}=756.06 \mathrm{x}-5.3676$ & 0.1392 \\
$\begin{array}{l}\text { Croissant } \\
\begin{array}{l}\text { Keju } \\
\text { Apple }\end{array}\end{array}$ & $\mathrm{y}=18.492 \mathrm{x}-3.9214$ & 0.0001 & $\mathrm{y}=-63.7670 \mathrm{x}-2.9059$ & 0.0009 \\
Danish & $\mathrm{y}=8598.5 \mathrm{x}-32.4750$ & 0.4170 & $\mathrm{y}=19447 \mathrm{x}-68.4320$ & 0.4942 \\
\hline
\end{tabular}

Tabel 3. Penentuan orde reaksi produk dan energi aktivasi

\begin{tabular}{lccc}
\hline \multicolumn{1}{c}{ Produk } & Persamaan Arrhenius & $\begin{array}{c}\text { Orde } \\
\text { Reaksi }\end{array}$ & $\begin{array}{c}\text { Umur Simpan } \\
\text { (Hari) }\end{array}$ \\
\hline $\begin{array}{l}\text { Croissant } \\
\text { Cokelat }\end{array}$ & $y=756.06 x-5.3676$ & 1 & 35.00 \\
$\begin{array}{l}\text { Croissant } \\
\text { Keju }\end{array}$ & $y=-63.7670 x-2.9059$ & 1 & 48.41 \\
$\begin{array}{l}\text { Apple } \\
\text { Danish }\end{array}$ & $y=19447 x-68.4320$ & 1 & 48.23 \\
\hline
\end{tabular}

Perhitungan umur simpan dengan menggunakan persamaan Arrhenius yang didapat dilakukan pada suhu $25^{\circ} \mathrm{C}$. Umur simpan croissant cokelat pada suhu ruang $\left(25^{\circ} \mathrm{C}\right)$ adalah 35 hari dan untuk croissant keju adalah 48 hari sedangkan untuk umur simpan danish sama dengan croissant keju yaitu 48 hari. Batas maksimum kadar MDA yang ditetapkan yaitu $0.6 \mathrm{mg} \mathrm{MDA} / \mathrm{g}$ sampel. Menurut Hafez (2012), nilai dengan rentang 0.65-1.44 mg MDA/g sampel sudah di anggap mengalami ketengi- 
kan, akan tetapi masih dapat diterima oleh konsumen. Selain itu pembungkus yang digunakan juga terbuat dari plastik OPP yang ditutup dengan perekat. Plastik OPP memiliki nilai transmisi oksigen sebesar $550 \mathrm{~cm} 3 / \mathrm{m} 2 /$ hari (Evergreen 2018). Sebagai salah satu alternatif untuk meningkatkan umur simpan dari produk pastry yang dihasilkan oleh UMKM dapat menggunakan pembungkus berupa alumunium foil yang memiliki nilai transmisi oksigen sebesar $0.0006 \mathrm{~cm} 3 / \mathrm{m} 2 /$ hari. Selain itu digunakan gas N2 yang bersifat inert sehingga dapat menjadi filler dan juga mencegah kerusakan bahan pangan karena menghambat proses oksidasi lemak (Hawa et al. 2010).

\section{Korelasi antara umur simpan dengan QDA dan Arrhenius}

Perhitungan umur simpan untuk ketiga produk baik dengan metode QDA maupun dengan Arrhenius dapat dilihat pada Tabel 4. Produk pastry dengan metode QDA memiliki daya simpan yang jauh lebih rendah jika dibandingkan dengan metode Arrhenius. Uji konfirmasi yang dilakukan dengan melihat tingkat ketengikan dianggap kurang representatif untuk produk ini terlihat dari jauhnya nilai yang didapat antar kedua metode tersebut.

Tabel 4. Perbandingan umur simpan

\begin{tabular}{lccc}
\hline \multicolumn{1}{c}{ Sampel } & QDA & Arrhenius & $\begin{array}{c}\text { Penerimaan Konsumen } \\
\text { (Ismail 2018) }\end{array}$ \\
\hline $\begin{array}{l}\text { Croissant } \\
\text { Cokelat } \\
\text { Croissant }\end{array}$ & 6 hari & 35 & $\begin{array}{c}5 \text { hari }(40 \% \text { panelis dapat } \\
\text { mendeteksi ketengikan) }\end{array}$ \\
$\begin{array}{l}\text { Keju } \\
\text { Apple } \\
\text { Danish }\end{array}$ & 6 hari & 48 & \\
\hline
\end{tabular}

Pertumbuhan kapang pada produk apple danish dihari keenam menunjukkan bahwa kerusakan yang lebih cepat terjadi yaitu kerusakan mikrobiologi akibat adanya aktivitas kapang. Kapang sangat mudah tumbuh pada produk bakery terlebih pada produk yang belum terkemas secara baik dan tidak menggunakan pengawet pada pembuatannya. Menurut Mizana et al. (2016), kapang pada roti tawar yang disimpan pada suhu ruang mulai teridentifikasi pada hari keempat. Jika dibandingkan dengan penerimaan konsumen umur simpan produk pastry tidak berbeda jauh yaitu selama 5 hari. Perhitungan umur simpan dengan metode QDA tersebut dapat dinyatakan sebagai umur simpan dengan High Quality Life (HQL) karena menggunakan panelis terlatih dalam pelaksanaannya. HQL menunjukkan umur simpan yang lebih pendek. Uji ini dilakukan dengan cara menghitung waktu ketika dirasakan adanya perubahan yang menyimpang berdasarkan uji sensori produk yang telah disimpan dengan produk yang baru diproduksi (Rahayu dan Arpah 2003).

\section{KESIMPULAN}

Umur simpan berdasarkan hasil QDA untuk masingmasing produk diantara apple danish dapat disimpan selama 6 hari, croissant cokelat selama 6 hari, dan croissant keju selama 5 hari. Jika berdasarkan metode Arrhenius dengan parameter berupa tingkat ketengikan produk maka umur simpan untuk masing-masing adalah 48 hari untuk apple danish, 35 hari untuk croissant cokelat dan 48 hari untuk croissant keju. Umur simpan dengan QDA memiliki nilai yang hampir sama dengan umur simpan bersarkan penerimaan konsumen. Perhitungan umur simpan dengan metode QDA tersebut dapat dinyatakan sebagai umur simpan dengan High Quality Life. Untuk itu umur simpan yang dianggap lebih tepat yaitu dengan uji sensori dibanding dengan uji Arrhenius karena umur simpan yang relatif pendek dari produk pastry.
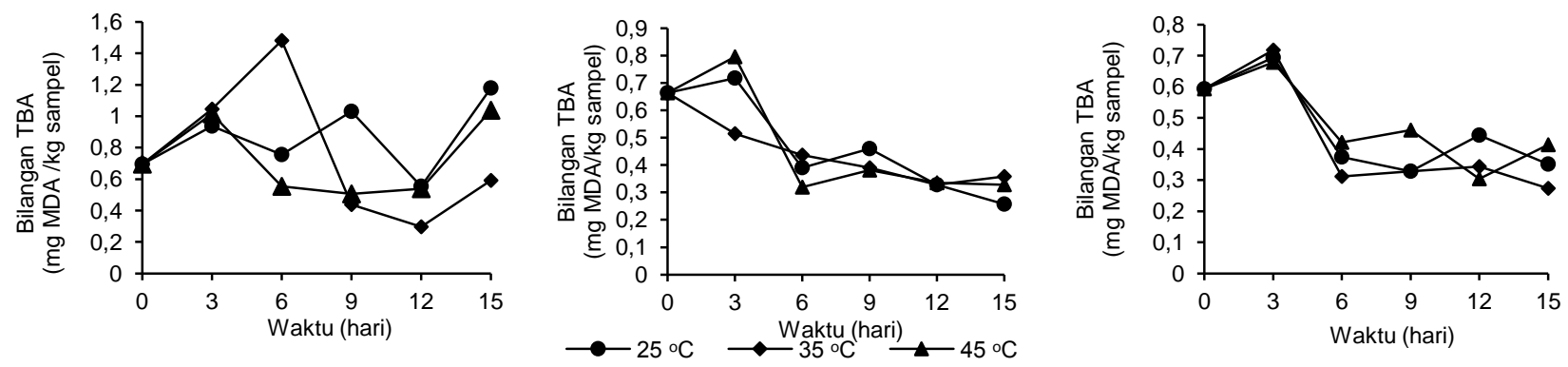

Gambar 5. Perubahan nilai TBA selama penyimpanan orde 0 (a) apple danish (b) croissant cokelat (c) croissant keju
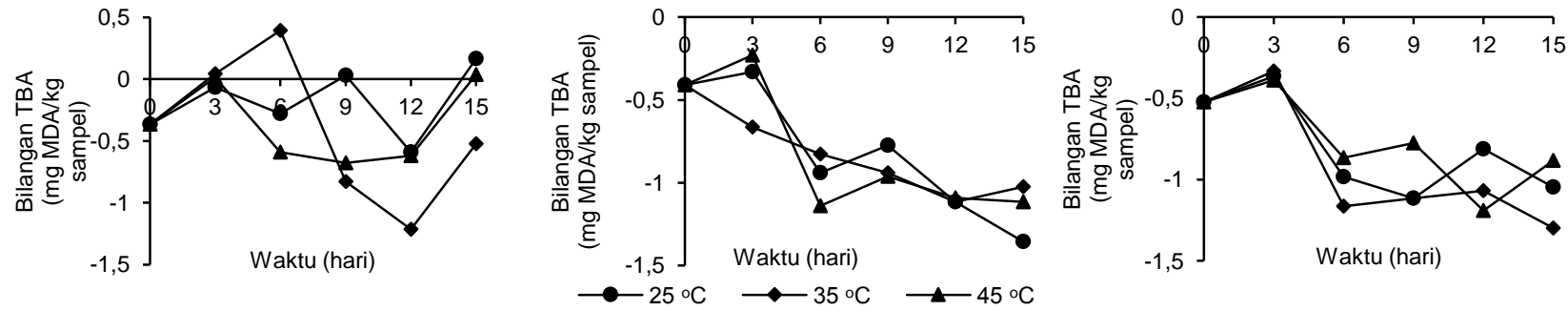

Gambar 6. Perubahan nilai TBA selama penyimpanan orde 1 (a) apple danish (b) croissant cokelat (c) croissant keju 


\section{DAFTAR PUSTAKA}

[AOAC] Association of Official Analytical Chemistry. 2012. Official method of Analysis. Association of Official Analytical Chemistry 19th Edition. Gaitherburg (US): AOAC.

Arkanti LW. 2007. Karakteristik Sifat Fisikokimia dan Sensori Beras Pandan Wangi, Morneng, dan BTN. [Skripsi]. Bogor (ID): Institut Pertanian Bogor.

Arpah M. 2007. Penetapan Waktu Kadaluwarsa Pangan. Bogor (ID): Departemen Ilmu dan Teknologi Pangan, Institut Pertanian Bogor.

[BPS] Badan Pusat Statistik. 2015. Jumlah Produksi Roti dan Jumlah Penduduk di Indonesia Tahun 20092013. htpp://www. bps.go.id. [14 Januari 2018].

[BSN] Badan Standardisasi Nasional. 2006. Standar Nasional Indonesia Nomor 01-2346-2006 tentang Petunjuk Pengujian Organoleptik dan atau Sensori. Jakarta (ID): BSN.

Budijanto S. Sitanggang AB. Kartika YD. 2010. Penentuan umur simpan tortilla dengan metode akselerasi berdasarkan kadar air kritis serta pemodelan ketepatan sorpsi isotherminya. J Teknol Industri Pangan 21(2): 165-170.

Desrosier NM. 2008. The Technology of Food Preservation, Third Edition (Teknologi Pengawetan Pangan, Edisi Ketiga). Penerjemah: Muchji Mulijohardjo. Jakarta (ID): Universitas Indonesia.

Evergreen. 2018. One-stop Service for Flexible Packaging: The Barrier Performace of Commom Plastic Film. www.flexpackaging.com. [Oktober 2018].

Global Industry Analysis. 2017. Per capita consumtion trends indicate untapped potential for growth in the world baking industry. www.strategyr.com/Market Research/. [30 November 2107].

Hafez AA. 2012. Physico-chemical and sensory properties of cakes supplemented with different concentration of marjoram. Australian J Basic Appl Sci 6(13): 463-470.

Hawa LC, Lastriyanto A, Bangun S. 2010. Pengemasan atmosfir termodifikasi beras pecah kulit dan sosoh. J Teknologi Pertanian 11(3): 177-183.

Heymann H, Lawless H. 2010. Sensory Evaluation of Food. Principles and Practices. 2nd Edition. New York (US): Springer Science \& Business Media New York.

Hozova B, Kukurova I, Turicova R, Dodok L. 2002. Sensory quality of stored croissant-type bakery products. Czech J Food Sci 20(3): 105-112.

Ismail NFB. 2018. Predicting the Shelf Life of Pastry Products with Consumer Flash Profiling. [Skripsi]. Bogor (ID): Institut Pertanian Bogor.

Ketaren S. 2005. Minyak dan Lemak Pangan. Jakarta (ID): UI Press.

Maharani DBKS, Fibrianto K. 2015. Implementasi content analysis dalam eksplorasi sensori lexicon susu pasteurisasi: kajian pustaka. J Pangan Agroindustri 3(4): 1567-1572.
Meilgaard MC, Civille GV, Carr BT. 2007. Sensory Evaluation Techniques. Florida (US): CRC Pr. Mizana DK, Suharti N, Amir A. 2016. Identifikasi pertumbuhan jamur Aspergilus sp. pada roti tawar yang dijual di kota padang berdasarkan suhu dan lama penyimpanan. J Kesehatan Andalas 5(2): 355360.

Negara HP, Lelana IYB, Ekantari N. 2014. Pengkayaan ß-karoten pada cokelat batang dengan panambahan Spirulina platensis. J Fish Sci16(1): 17-28.

Oliveira ADN, Ramos AM, Minim VPR, Chaves JBP. 2012. Sensory stability of whole mango juice: influence of temperature and storage time. Cienc Tecnol Aliment Campinas 32(4): 819-825.

Patra E. 2016. Using Sensory Shelf lifeTesting to Drive Consumer Satisfaction. Epsom (UK): Leatherhead Food Research.

Pratomodjati. 2007. Mempelajari Pengaruh Pemanasan Terhadap Mutu Keju Olahan. [Tesis]. Bogor (ID): Institut Pertanian Bogor.

Rahayu WP, Arpah M. 2003. Penuntun Teknis: Penetapan Kadaluarsa Produk Industri Kecil Pangan. Bogor (ID): Departemen Ilmu dan Teknologi Pangan, Fateta, IPB.

Rahmadhani R, Fibrianto K. 2016. Proses penyiapan mahasiswa sebagai panelis terlatih dalam pengembangan lexicon (bahasa sensori) susu skim UHT dan susu kaya lemak UHT. J Pangan Agroindustri 4(1): 190-200.

Rahmawati D, Andarwulan N, Lioe HN. 2015. Identifikasi atribut rasa dan aroma mayonnaise dengan metode Quantitative Descriptive Analysis (QDA). JMutu Pangan 2(2): 80-87.

Saloko S, Nazariddin, Handito D, Cicilia S, Dwiani A. 2016. Karakteristik fisikokimia dan sensori produk patiseri berbasis mocaf. J Rekayasa Pangan 10(1): 36-42.

Sans RG, Chozas MG. 1998. The thiobarbituric acid (TBA) reaction in food: a review. Crit Rev Food Sci Nutr 38(4): 315-330.

Sharma R, Chisti Y, Banerjee CU. 2001. Production, purification, characterization, and applications of lipases. Biotechnol Advan 19: 627-662.

Sartika RAD. 2009. Pengaruh suhu dan lama menggoreng (deep frying) terhadap pembentukan asam lemak trans. Makara Sains 13(1): 23-28.

Steele R. 2009. Understanding and Measurin the Shelflife of Food. Boca Raton (US): Woodhead Publishing Limited and CRC Press.

Tarladgis BG, Watts BM, Younathan MT, Dugan L Jr. 1960. Distillation Method for the quantitative determination of malonaldehyde in rancid foods. J Am Oil Chemist Society 37(1): 44-48.

Utami IS, Tranggono, Hastuti P. 2006. Evaluasi sensori odor bubuk merica hitam (Pepernigrum L) selama penyimpanan dengan olfaktometer static. Agritech 25(4): 195-199.

JMP-03-19-03-Naskah diterima untuk ditelaah pada 12 Maret 2019. Revisi makalah disetujui untuk dipublikasi pada 16 Oktober 2019. Versi Online: http://journal.ipb.ac.id/index.php/jmpi 